\title{
Biochemical and Molecular Analysis of Superoxide Dismutase in Sordaria fimicola and Aspergillus niger Collected from Different Environments
}

\author{
Muhammad Ishfaq ${ }^{1 *}$, Nasir Mahmood ${ }^{2}$, Idrees A. Nasir ${ }^{3}$, \\ Muhammad Saleem ${ }^{1}$ \\ ${ }^{1}$ Molecular Genetics Research Laboratory, Department of Botany, University of the Punjab, Lahore, Pakistan \\ ${ }^{2}$ Department of Biochemistry; Human Genetics and Molecular Biology, University of Health Sciences, \\ Lahore, Pakistan \\ ${ }^{3}$ Centre of Excellence in Molecular Biology, University of the Punjab, Lahore, Pakistan
}

Received: 15 July 2016

Accepted: 16 August 2016

\begin{abstract}
We evaluated Sordaria fimicola strains collected from benign and harsh environments of Evolution Canyon 1 (EC 1) for superoxide dismutase (SOD) enzyme activity, and analyzed their respective gene sequences, which were then submitted to the NCBI database for the first time. Ten strains of Aspergillus niger were used as control in a SOD assay. In enzymatic analysis, among 61 isolates the N6 strain of S. fimicola was found to be the most efficient as it caused 50\% inhibition of NBT (Nitro-blue tetrazolium) reduction at $20 \mu \mathrm{g}$ of the SOD protein, while in $A$. niger, strain 744 showed $60 \%$ inhibition of the NBT reduction at $40 \mu \mathrm{g}$ amount of SOD protein and was found to be most efficient among $A$. niger. The superoxide dismutase- 1 (SOD-1) gene (including exones and introns; 960 bases) was amplified and sequenced from biochemically efficient strains of S. fimicola viz. N6, N7, S2, S1, and SF13, and submitted to the NCBI database under accession numbers KM282180, KM282181, KM282179, KM282178, and KM282177, respectively. On comparison with the reported sequence of Neurospora crassa (M58687.1), a total of 25 base substitutions and seven amino acids changes were detected in the in silico translated proteins of all five strains of S. fimicola compared to the reference sequence of $N$. crassa (M18334.1). The biochemical as well as molecular data of the study proved that environmental stresses affected the SOD-1 gene by bringing in mutations, which may result in genomic diversity among their frontier molecules such as proteins. The observed enzymatic activity of SOD in S. fimicola strains was reported to be even better and was comparable to A. niger strains, and thus $S$. fimicola strains can be exploited further for enzymatic production for industrial use.
\end{abstract}

Keywords: Sordaria fimicola, Aspergillus niger, SOD enzyme, SOD-1 gene, phylogenetic analysis

*e-mail: ishfaq.botany@pu.edu.pk 


\section{Introduction}

Filamentous fungi secrete different enzymes in growth medium, and most of these enzymes are hydrolytic in nature and employed in different industrial processes [1]. Fungi belonging to Ascomycota are decomposers in most ecosystems, making an important contribution to the ecological balance and also having great industrial application due to the presence of different enzymes [2]. A total of 16 fungal enzymes are used in the food industry and 13 of them have been obtained from Aspergillus [3].

Superoxide dismutase (SOD, EC 1.15.1.1) is present in all living organisms that efficiently transform superoxide $\left(\mathrm{O}_{2}^{-}\right)$into hydrogen peroxide $\left(\mathrm{H}_{2} \mathrm{O}_{2}\right)$ and molecular oxygen [4]. Superoxide dismutases are well described in prokaryotic and eukaryotic cells and have proven to be universal protective tools that protect the cell from damage [5]. An ample quantity of fungal $\mathrm{Cu} / \mathrm{Zn}$ superoxide dismutase was detected; even from a small amount of fungal biomass, which indicates that it protects the fungus form reactive oxygen species [6]. The antioxidant activity of Tolypocladium fungus isolated from Camellia sinesis, an endangered species, has been studied [7]. A $S O D$ gene from the thermophilic fungus Chaetomium thermophilum (CtSOD) was cloned and expressed in Pichia pastoris, which was confirmed as belonging to the type of $\mathrm{Cu} / \mathrm{Zn}-\mathrm{SOD}$ [8]. The broad range of SOD application in the pharmaceutical, food, and cosmetics industries has led investigators to clone SOD genes from various animals [9], plants [10], and microorganisms [11].

In the current research work, Sordaria fimicola strains were evaluated for the first time for their SOD enzyme activity, and their respective genes were analyzed by taking into consideration the fact that being a saprophytic fungus $S$. fimicola may have the ability to produce relatively higher levels of this enzyme.

\section{Materials and Methods}

\section{Organisms, Culture Media, Culture Revival, and Sub Culturing}

We used the S. fimicola (Roberge ex Desm.) Ces. and De Not., and A. niger (Tiegh) strains throughout the study. Sixty strains of S. fimicola collected from Evolution Canyon 1 (EC I) in Mount Carmel, Israel, and one strain SF13 obtained from the University of Illinois at UrbanaChampaign, USA, were used in the current research. EC 1 has two opposite slopes: a south-facing slope (SFS) with terrestrial climate and a north-facing slope (NFS) with a temperate climate [12]. Stations 1 and 2 are located on the SFS at elevations of 120 and $90 \mathrm{~m}$, respectively, while stations 6 and 7 are located on the NFS at 120 and 180 $\mathrm{m}$ above sea level, respectively. From each station we used 15 samples. In addition, 10 isolates of $A$. niger were purchased from the First Fungal Culture Bank of Pakistan (FCBP), Institute of Agricultural Sciences, University of the Punjab; they had all been isolated from different locations within Pakistan [13]. Stock cultures of S. fimicola and $A$. niger were revived by using potato dextrose agar (PDA) medium. Actively growing mycelium of fungi were transferred on the PDA media and incubated at $18^{\circ} \mathrm{C}$ for $S$. fimicola and $25^{\circ} \mathrm{C}$ for $A$. niger for seven days to get good mycelium mat for DNA extraction. For biochemical analysis, fungal mycelium of both $S$. fimicola and $A$. niger were subculture in the PD broth medium and incubated in a shaker at their respective temperatures for seven days.

\section{Total Secretory Protein Estimation and SOD Assay}

Whatman filter paper No. 1 was used to separate the filtrate from fungal biomass and $5 \mathrm{~mL}$ filtrate was used for subsequent analysis. Total proteins estimation of the fungal filtrate was carried out according to the Bradford method [14]. The BSA (bovine serum albumin) standard curve was plotted in order to determine the amount of total secretory protein of each fungal strain, and then SOD level in growth medium filtrate of each fungal strain of S. fimicola and A. niger was determined. Briefly, purified powdered SOD enzyme (Sigma Aldrich, Cat No. S9697) in different amounts $(0,2,4,8$, and $16 \mu \mathrm{g})$ was constituted in $0.1 \mathrm{~mL}$ of $10 \mathrm{mM} \mathrm{KPO}_{4}(\mathrm{pH} \mathrm{7.4)}$ and added in $0.2 \mathrm{~mL}$ of $0.1 \mathrm{M}$ EDTA solution, $0.1 \mathrm{~mL}$ of $1.5 \mathrm{mM}$ NBT (Nitro-blue tetrazolium), and $0.05 \mathrm{~mL}$ of $0.12 \mathrm{mM}$ Riboflavin, and final volume was made up to $3.0 \mathrm{~mL}$ with $0.067 \mathrm{M}$ Potassium phosphate buffer $(\mathrm{pH}$ 7.8). A sample mixture devoid of purified SOD enzyme was used as negative control. We incubated all the tubes at $25^{\circ} \mathrm{C}$ containing different amounts of purified SOD enzyme for 5.30 minutes time duration in which after every 30 -second time interval change in absorbance $\Delta \mathrm{A}$ value at $550 \mathrm{~nm}$ was determined for each sample containing different amounts of SOD protein. $\Delta \mathrm{A}_{550 \mathrm{~nm}}$ per minute for purified reference SOD protein at different amounts was calculated by the following formula:

$\Delta \mathrm{A}_{550 \mathrm{~nm}} / \min =\frac{\Delta \mathrm{A}_{550 \mathrm{~nm}} @ 5: 30-\Delta \mathrm{A}_{550 \mathrm{~nm}} @ 0: 30}{5}$

The above formula is used for positive control (containing purified reference SOD protein different amounts); negative control (containing all reaction mixture components except purified reference SOD protein); and experimental samples (containing different amounts of fungal filtrates as positive control). The $\Delta \mathrm{A}_{550}$ $\mathrm{nm} / \mathrm{min}$ values of positive control, negative control, and experimental samples were used to further to determine the percentage inhibition of NBT reduction by using the following formula:

Inhibition of NBT reduction $(\%)=$

$\frac{\Delta \mathrm{A}_{550 \mathrm{~nm}} / \mathrm{min}\left(\text { Negative Control) }-\Delta \mathrm{A}_{550 \mathrm{~nm}} / \mathrm{min} \text { (Positive Control) }\right.}{\Delta \mathrm{A}_{550} / \mathrm{min}(\text { Negative Control) }} \times 100$ 
Table 1. Superoxide dismutase assay of Aspergillus niger.

\begin{tabular}{|c|c|c|c|c|c|c|}
\hline \multirow{3}{*}{\multicolumn{2}{|c|}{$\begin{array}{c}\text { Absorbance } \\
\left(\Delta \mathrm{A}_{550 \mathrm{~nm}} / \mathrm{min}\right)\end{array}$}} & \multicolumn{5}{|c|}{ Amount of Pure SOD } \\
\hline & & $0 \mu \mathrm{g}$ & $2 \mu \mathrm{g}$ & $4 \mu \mathrm{g}$ & $8 \mu \mathrm{g}$ & $16 \mu \mathrm{g}$ \\
\hline & & $0.040(0.00 \%)$ & $0.031(22.5 \%)$ & $0.025(37.5 \%)$ & $0.020(50 \%)$ & $0.01(75 \%)$ \\
\hline \multirow{2}{*}{ Sr. No. } & \multirow{2}{*}{ Strains } & \multicolumn{5}{|c|}{ Amount of samples } \\
\hline & & \multicolumn{2}{|c|}{$10 \mu \mathrm{g}$} & $20 \mu \mathrm{g}$ & $40 \mu \mathrm{g}$ & $80 \mu \mathrm{g}$ \\
\hline 1 & 0002 & \multicolumn{2}{|c|}{$0.035(12.5 \%)$} & $0.033(17.5 \%)$ & $0.030(25 \%)$ & $0.022(45 \%)$ \\
\hline 2 & 0074 & \multicolumn{2}{|c|}{$0.036(10 \%)$} & $0.034(15 \%)$ & $0.030(25 \%)$ & $0.023(42.5 \%)$ \\
\hline 3 & 506 & \multicolumn{2}{|c|}{$0.036(10 \%)$} & $0.034(15 \%)$ & $0.030(25 \%)$ & $0.020(50 \%)$ \\
\hline 4 & 658 & \multicolumn{2}{|c|}{$0.036(10 \%)$} & $0.035(12.5 \%)$ & $0.031(22.5 \%)$ & $0.028(30 \%)$ \\
\hline 5 & 744 & \multicolumn{2}{|c|}{$0.026(35 \%)$} & $0.022(45 \%)$ & $0.016(60 \%)$ & $0.011(72.5 \%)$ \\
\hline 6 & 764 & \multicolumn{2}{|c|}{$0.032(20 \%)$} & $0.030(25 \%)$ & $0.028(30 \%)$ & $0.018 \quad(55 \%)$ \\
\hline 7 & 840 & \multicolumn{2}{|c|}{$0.036(10 \%)$} & $0.034(15 \%)$ & $0.033(17.5 \%)$ & $0.031(22.5 \%)$ \\
\hline 8 & 880 & \multicolumn{2}{|c|}{$0.032(20 \%)$} & $0.028(30 \%)$ & $0.024(40 \%)$ & $0.017(57.5 \%)$ \\
\hline 9 & 1005 & \multicolumn{2}{|c|}{$0.034(15 \%)$} & $0.032(20 \%)$ & $0.029(27.5 \%)$ & $0.019(52.5 \%)$ \\
\hline 10 & 1109 & \multicolumn{2}{|c|}{$0.037(7.5 \%)$} & $0.034(15 \%)$ & $0.031(22.5 \%)$ & $0.024(40 \%)$ \\
\hline
\end{tabular}

Note: The values in parenthesis indicated inhibition percentages of NBT reduction.

Table 2. Superoxide dismutase assay of Sordaria fimicola strains from Station 1 and SF13.

\begin{tabular}{|c|c|c|c|c|c|c|}
\hline \multirow{3}{*}{\multicolumn{2}{|c|}{$\begin{array}{c}\text { Absorbance } \\
\left(\Delta \mathrm{A}_{550 \mathrm{~nm}} / \mathrm{min}\right)\end{array}$}} & \multicolumn{5}{|c|}{ Amount of Pure SOD } \\
\hline & & $0 \mu \mathrm{g}$ & $2 \mu \mathrm{g}$ & $4 \mu \mathrm{g}$ & $8 \mu \mathrm{g}$ & $16 \mu \mathrm{g}$ \\
\hline & & $0.040(0.00 \%)$ & $0.031(22.5 \%)$ & $0.025(37.5 \%)$ & $0.020(50 \%)$ & $0.01(75 \%)$ \\
\hline \multirow{2}{*}{ Sr. No. } & \multirow{2}{*}{ Strains } & \multicolumn{5}{|c|}{ Amount of samples } \\
\hline & & \multicolumn{2}{|c|}{$10 \mu \mathrm{g}$} & $20 \mu \mathrm{g}$ & $40 \mu \mathrm{g}$ & $80 \mu \mathrm{g}$ \\
\hline 1 & AR25.4 & \multicolumn{2}{|c|}{$0.037(7.5 \%)$} & $0.035(12.5 \%)$ & $0.032(20 \%)$ & $0.028(30 \%)$ \\
\hline 2 & AR33.3 & \multicolumn{2}{|c|}{$0.039(2.5 \%)$} & $0.038(5 \%)$ & $0.036(10 \%)$ & $0.033(17.5 \%)$ \\
\hline 3 & AR24.8 & \multicolumn{2}{|c|}{$0.037(7.5 \%)$} & $0.036(10 \%)$ & $0.032(20 \%)$ & $0.031(22.5 \%)$ \\
\hline 4 & S1 & \multicolumn{2}{|c|}{$0.027(32.5 \%)$} & $0.023(42.5 \%)$ & $0.018(55 \%)$ & $0.013(67.5 \%)$ \\
\hline 5 & AR32.4 & \multicolumn{2}{|c|}{$0.035(12.5 \%)$} & $0.031(22.5 \%)$ & $0.027(32.5 \%)$ & $0.025(37.5 \%)$ \\
\hline 6 & AR59.2 & \multicolumn{2}{|c|}{$0.034(15 \%)$} & $0.032(20 \%)$ & $0.029(27.5 \%)$ & $0.024(40 \%)$ \\
\hline 7 & AR8.7 & \multicolumn{2}{|c|}{$0.036(10 \%)$} & $0.035(12.5 \%)$ & $0.031(22.5 \%)$ & $0.029(27.5 \%)$ \\
\hline 8 & AR55.5 & \multicolumn{2}{|c|}{$0.033(17.5 \%)$} & $0.030(25 \%)$ & $0.026(35 \%)$ & $0.023(42.5 \%)$ \\
\hline 9 & AR16.1 & \multicolumn{2}{|c|}{$0.039(2.5 \%)$} & $0.038(5 \%)$ & $0.034(15 \%)$ & $0.032(20 \%)$ \\
\hline 10 & AR53.2 & \multicolumn{2}{|c|}{$0.037(7.5 \%)$} & $0.033(17.5 \%)$ & $0.032(20 \%)$ & $0.030(25 \%)$ \\
\hline 11 & AR17.2 & \multicolumn{2}{|c|}{$0.035(12.5 \%)$} & $0.033(17.5 \%)$ & $0.030(25 \%)$ & $0.027(32.5 \%)$ \\
\hline 12 & AR66.2 & \multicolumn{2}{|c|}{$0.038(5 \%)$} & $0.037(7.5 \%)$ & $0.035(12.5 \%)$ & $0.03(20 \%)$ \\
\hline 13 & AR28.8 & \multicolumn{2}{|c|}{$0.036(10 \%)$} & $0.035(12.5 \%)$ & $0.031(22.5 \%)$ & $0.028(30 \%)$ \\
\hline 14 & AR15.7 & \multicolumn{2}{|c|}{$0.035(12.5 \%)$} & $0.034(15 \%)$ & $0.031(22.5 \%)$ & $0.027(32.5 \%)$ \\
\hline 15 & AR21.3 & \multicolumn{2}{|c|}{$0.034(15 \%)$} & $0.029(27.5 \%)$ & $0.026(35 \%)$ & $0.025(37.5 \%)$ \\
\hline 16 & SF13 & \multicolumn{2}{|c|}{$0.032(20 \%)$} & $0.028(30 \%)$ & $0.024(40 \%)$ & $0.022(45 \%)$ \\
\hline
\end{tabular}

Note: The values in parenthesis indicated inhibition percentages of NBT reduction. 
Table 3. Superoxide dismutase assay of Sordaria fimicola strains from Station 2.

\begin{tabular}{|c|c|c|c|c|c|c|}
\hline \multirow{3}{*}{\multicolumn{2}{|c|}{$\begin{array}{l}\text { Absorbance } \\
\left(\Delta \mathrm{A}_{550 \mathrm{~nm}} / \mathrm{min}\right)\end{array}$}} & \multicolumn{5}{|c|}{ Amount of Pure SOD } \\
\hline & & $0 \mu \mathrm{g}$ & $2 \mu \mathrm{g}$ & $4 \mu \mathrm{g}$ & $8 \mu \mathrm{g}$ & $16 \mu \mathrm{g}$ \\
\hline & & $0.040(0.00 \%)$ & $0.031(22.5 \%)$ & $0.025(37.5 \%)$ & $0.020(50 \%)$ & $0.01(75 \%)$ \\
\hline \multirow{2}{*}{ Sr. No. } & \multirow{2}{*}{ Strains } & \multicolumn{5}{|c|}{ Amount of samples } \\
\hline & & \multicolumn{2}{|c|}{$10 \mu \mathrm{g}$} & $20 \mu \mathrm{g}$ & $40 \mu \mathrm{g}$ & $80 \mu \mathrm{g}$ \\
\hline 1 & IQ36.5 & \multicolumn{2}{|c|}{$0.036(10 \%)$} & $0.034(15 \%)$ & $0.030(25 \%)$ & $0.023(42.5 \%)$ \\
\hline 2 & IQ18.3 & \multicolumn{2}{|c|}{$0.038(5 \%)$} & $0.036(10 \%)$ & $0.031(22.5 \%)$ & $0.031(22.5 \%)$ \\
\hline 3 & IQ38.3 & \multicolumn{2}{|c|}{$0.039(2.5 \%)$} & $0.037(7.5 \%)$ & $0.036(10 \%)$ & $0.033(17.5 \%)$ \\
\hline 4 & IQ8.4 & \multicolumn{2}{|c|}{$0.037(7.5 \%)$} & $0.036(10 \%)$ & $0.031(22.5 \%)$ & $0.024(40 \%)$ \\
\hline 5 & IQ3.2 & \multicolumn{2}{|c|}{$0.035(12.5 \%)$} & $0.031(22.5 \%)$ & $0.027(32.5 \%)$ & $0.025(37.5 \%)$ \\
\hline 6 & S2 & \multicolumn{2}{|c|}{$0.030(25 \%)$} & $0.027(32.5 \%)$ & $0.022(45 \%)$ & $0.018(55 \%)$ \\
\hline 7 & IQ15.7 & \multicolumn{2}{|c|}{$0.036(10 \%)$} & $0.035(12.5 \%)$ & $0.033(17.5 \%)$ & $0.030(25 \%)$ \\
\hline 8 & IQ39.1 & \multicolumn{2}{|c|}{$0.033(17.5 \%)$} & $0.030(25 \%)$ & $0.026(35 \%)$ & $0.025(37.5 \%)$ \\
\hline 9 & IQ26.3 & \multicolumn{2}{|c|}{$0.036(10 \%)$} & $0.035(12.5 \%)$ & $0.031(22.5 \%)$ & $0.026(35 \%)$ \\
\hline 10 & IQ7.2 & \multicolumn{2}{|c|}{$0.037(7.5 \%)$} & $0.033(17.5 \%)$ & $0.032(20 \%)$ & $0.030(25 \%)$ \\
\hline 11 & IQ32.4 & \multicolumn{2}{|c|}{$0.035(12.5 \%)$} & $0.034(15 \%)$ & $0.031(22.5 \%)$ & $0.027(32.5 \%)$ \\
\hline 12 & IQ4.5 & \multicolumn{2}{|c|}{$0.038(5 \%)$} & $0.037(7.5 \%)$ & $0.035(12.5 \%)$ & $0.032(20 \%)$ \\
\hline 13 & IQ17.8 & \multicolumn{2}{|c|}{$0.036(10 \%)$} & $0.035(12.5 \%)$ & $0.031(22.5 \%)$ & $0.028(30 \%)$ \\
\hline 14 & IQ21.4 & \multicolumn{2}{|c|}{$0.034(15 \%)$} & $0.031(22.5 \%)$ & $0.030(25 \%)$ & $0.028(30 \%)$ \\
\hline 15 & IQ27.7 & \multicolumn{2}{|c|}{$0.039(2.5 \%)$} & $0.038(5 \%)$ & $0.034(15 \%)$ & $0.033(17.5 \%)$ \\
\hline
\end{tabular}

Note: The values in parenthesis indicated inhibition percentages of NBT reduction.

\section{DNA Extraction and Ribotyping}

The 1\% CTAB method with slight modifications [15] was used for DNA isolation from S. fimicola strains. The quality of extracted DNA was checked by running $1 \%$ agarose gel electrophoresis, and quantification was done by taking absorbance at $260 \mathrm{~nm}$ using a UV spectrophotometer (UV 1800 SHIMADZU). Sordaria fimicola found to be efficient in SOD enzyme production were subjected to ribotyping by amplification of the 431 base long hyper variable (V4) region of 18S rRNA gene [16].

\section{SOD-1 Gene Amplification and Sequencing}

For SOD-1 gene amplification in S. fimicola different primers sets were designed by using the reference gene sequence of $N$. crassa (M58687.1). The nucleotide structure pairs were 5' ACCGCTTCTACCCAAGCA 3' for SOD-F and 5' GTGTTGTCACCGAAGGTGT 3' for SOD-R (with expected PCR product of size $486 \mathrm{bp}$ ), while 5' CGTCAAGGGCACCGTGAT 3' for SODM-F and 5' TTACTGGGAGATACCAATGAC 3' for SODM-R (with expected PCR product of size $585 \mathrm{bp}$ ) were used for SOD-1 gene amplification. The PCR conditions were optimized by adjusting different melting temperatures and $\mathrm{MgCl}_{2}$ concentrations. Primers and standard reagents were supplied by Promega, Madison, WI, USA. The $50 \mu \mathrm{L}$ reaction mixture containing $10 \mu \mathrm{L}$ Go Taq flexi Buffer (5x), 3.0-6.0 $\mu \mathrm{L} \mathrm{MgCl}_{2}(1.5-3.00 \mathrm{mM}), 1.0 \mu \mathrm{L}$ dNTPs (10 mM each), $0.5 \mu \mathrm{L}$ Go Taq DNA Polymerase $(5 \mathrm{U} / \mu \mathrm{L}), 0.2 \mu \mathrm{L}$ of each upstream and downstream primer $(25 \mathrm{pmole} / \mu \mathrm{L})$ and template DNA $(25 \mathrm{ng} / \mu \mathrm{L})$ was prepared and PCR tubes were placed in the PCR machine (Applied Biosystems, 2720 Thermocycler, USA). Temperature cycling conditions were adjusted as initial denaturation at $94^{\circ} \mathrm{C}$ for 3 minutes, followed by 35 cycles of denaturation at $94^{\circ} \mathrm{C}$ for 1 minute, annealing at $50-60^{\circ} \mathrm{C}$ in independent reactions for 1 minute, primer extension at $72^{\circ} \mathrm{C}$ for 1 minute, final extension at $72^{\circ} \mathrm{C}$ for 7 minutes, and the reaction was terminated at $4^{\circ} \mathrm{C}$. The amplified products were checked by $1 \%$ agarose gel electrophoresis and DNA bands were purified from the gel using standard reagents supplied by Promega. Gel-purified PCR products were sequenced in both directions from the Core sequencing facility, UIUC, USA.

Chromas, ClustalW, and protein translation tools available at ExPASy Protparam were used to draw a useful conclusion. The post-translational modifications (PTMs) potential was predicted for SOD-1 protein by using different servers like LysAcet and PredMod for acetylation; BPS for methylation; and DISPHOS and 
Table 4. Superoxide dismutase assay of Sordaria fimicola strains from Station 6.

\begin{tabular}{|c|c|c|c|c|c|c|}
\hline & & \multicolumn{5}{|c|}{ Amount of Pure SOD } \\
\hline \multirow{2}{*}{\multicolumn{2}{|c|}{$\begin{array}{c}\text { Absorbance } \\
\left(\Delta \mathrm{A}_{550 \mathrm{~nm}} / \mathrm{min}\right)\end{array}$}} & $0 \mu \mathrm{g}$ & $2 \mu \mathrm{g}$ & $4 \mu \mathrm{g}$ & $8 \mu \mathrm{g}$ & $16 \mu \mathrm{g}$ \\
\hline & & $0.040(0.00 \%)$ & $0.031(22.5 \%)$ & $0.025(37.5 \%)$ & $0.020(50 \%)$ & $0.01(75 \%)$ \\
\hline \multirow{2}{*}{ Sr. No. } & \multirow{2}{*}{ Strains } & \multicolumn{5}{|c|}{ Amount of samples } \\
\hline & & \multicolumn{2}{|c|}{$10 \mu \mathrm{g}$} & $20 \mu \mathrm{g}$ & $40 \mu \mathrm{g}$ & $80 \mu \mathrm{g}$ \\
\hline 1 & N6 & \multicolumn{2}{|c|}{$0.027(32.5 \%)$} & $0.018(55 \%)$ & $0.013(67.5 \%)$ & $0.011(72.5 \%)$ \\
\hline 2 & MQ18.2 & \multicolumn{2}{|c|}{$0.035(7.5 \%)$} & $0.032(20 \%)$ & $0.029(27.5 \%)$ & $0.026(35 \%)$ \\
\hline 3 & MQ13.4 & \multicolumn{2}{|c|}{$0.033(17.5 \%)$} & $0.030(25 \%)$ & $0.026(35 \%)$ & $0.023(42.5 \%)$ \\
\hline 4 & MQ15.4 & \multicolumn{2}{|c|}{$0.037(7.5 \%)$} & $0.036(10 \%)$ & $0.032(20 \%)$ & $0.031(22.5 \%)$ \\
\hline 5 & MQ1.8 & \multicolumn{2}{|c|}{$0.035(12.5 \%)$} & $0.031(22.5 \%)$ & $0.027(32.5 \%)$ & $0.025(37.5 \%)$ \\
\hline 6 & MQ5.4 & \multicolumn{2}{|c|}{$0.034(15 \%)$} & $0.032(20 \%)$ & $0.029(27.5 \%)$ & $0.024(40 \%)$ \\
\hline 7 & MQ45.5 & \multicolumn{2}{|c|}{$0.036(10 \%)$} & $0.035(12.5 \%)$ & $0.031(22.5 \%)$ & $0.029(27.5 \%)$ \\
\hline 8 & MQ16.6 & \multicolumn{2}{|c|}{$0.034(15 \%)$} & $0.033(17.5 \%)$ & $0.029(27.5 \%)$ & $0.033(32.5 \%)$ \\
\hline 9 & MQ19.2 & \multicolumn{2}{|c|}{$0.038(5 \%)$} & $0.037(7.5 \%)$ & $0.035(12.5 \%)$ & $0.030(25 \%)$ \\
\hline 10 & MQ7.7 & \multicolumn{2}{|c|}{$0.034(15 \%)$} & $0.029(27.5 \%)$ & $0.026(35 \%)$ & $0.025(37.5 \%)$ \\
\hline 11 & MQ12.4 & \multicolumn{2}{|c|}{$0.035(12.5 \%)$} & $0.033(17.5 \%)$ & $0.030(25 \%)$ & $0.027(32.5 \%)$ \\
\hline 12 & MQ11.2 & \multicolumn{2}{|c|}{$0.038(5 \%)$} & $0.037(7.5 \%)$ & $0.035(12.5 \%)$ & $0.032(20 \%)$ \\
\hline 13 & MQ8.1 & \multicolumn{2}{|c|}{$0.036(10 \%)$} & $0.035(12.5 \%)$ & $0.031(22.5 \%)$ & $0.028(30 \%)$ \\
\hline 14 & MQ52.7 & \multicolumn{2}{|c|}{$0.035(12.5 \%)$} & $0.034(15 \%)$ & $0.031(22.5 \%)$ & $0.027(32.5 \%)$ \\
\hline 15 & MQ17.6 & \multicolumn{2}{|c|}{$0.038(5 \%)$} & $0.036(10 \%)$ & $0.033(17.5 \%)$ & $0.031(22.5 \%)$ \\
\hline
\end{tabular}

Note: The values in parenthesis indicated inhibition percentages of NBT reduction.

YinOYang for phosphorylation; while NetNGlyc 1.0 and YinOYang were used for glycosylation.

\section{Phylogenetic Analysis}

All available sequences of SOD-1 gene in the gene bank database were extracted and aligned with ClastalW program. Molecular Evolutionary Genetics Analysis (MEGA 6.0.5) software was used for sequence alignments and phylogenetic analysis [17]. The nucleotide sequences of the S. fimicola of SOD-1 gene were submitted to the NCBI database.

\section{Results}

\section{SOD Assay}

Superoxide dismutase enzyme activity in different strains of $A$. niger and $S$. fimicola was determined in terms of percentage inhibition of NBT reduction. The purified reference SOD protein showed 50\% inhibition of NBT reduction in the amount of $8 \mu \mathrm{g}$ (Table 1). In the SOD assay, among 10 isolates of $A$. niger, strain 744 showed $60 \%$ inhibition of NBT reduction at $40 \mu \mathrm{g}$ of filtrate protein and was found to be the most efficient strain in SOD enzyme activity (Table 1). However, strain 840 showed the least inhibition percentage of NBT reduction and even $80 \mu \mathrm{g}$ protein of the filtrate caused only $22.5 \%$ inhibition of NBT reduction (Table 1). Strains 506, 764, 880, and 1,005 of $A$. niger showed the same level of SOD production and $50 \%$ inhibition of NBT reduction was observed at protein concentration of $80 \mu \mathrm{g}$ (Table 1). While A. niger strains $0002,0074,658$, and 1,109 showed up to $45 \%$ inhibition of NBT reduction at maximum amount of filtrate proteins, i.e., $80 \mu \mathrm{g}$ (Table 1).

As regards SOD enzyme activity of S. fimicola, the S1 strain from stations 1 of EC 1 showed 55\% inhibition of the NBT reduction at a $40 \mu \mathrm{g}$ amount of filtrate protein and was found to be the most efficient strain in SOD enzyme activity (Table 2). Strain AR55.5 was represented as the second most-efficient strain and showed $42.5 \%$ inhibition of NBT reduction at protein concentration of $80 \mu \mathrm{g}$ (Table 2). Remaining strains of $S$. fimicola from Station 1 exhibited almost the same level of NBT inhibition (Table 2). However, strain AR33.3 showed the least inhibition percentage of NBT reduction and even $80 \mu \mathrm{g}$ protein of filtrate caused only $17.5 \%$ inhibition of NBT reduction (Table 2). While S. fimicola strain SF13 showed better response than strain AR55.5 regarding SOD production, it showed $45 \%$ inhibition of NBT reduction at $80 \mu \mathrm{g}$ (Table 2). 
Table 5. Superoxide dismutase assay of Sordaria fimicola strains from Station 7.

\begin{tabular}{|c|c|c|c|c|c|c|}
\hline \multirow{3}{*}{\multicolumn{2}{|c|}{$\begin{array}{l}\text { Absorbance } \\
\left(\Delta \mathrm{A}_{550 \mathrm{~nm}} / \mathrm{min}\right)\end{array}$}} & \multicolumn{5}{|c|}{ Amount of Pure SOD } \\
\hline & & $0 \mu \mathrm{g}$ & $2 \mu \mathrm{g}$ & $4 \mu \mathrm{g}$ & $8 \mu \mathrm{g}$ & $16 \mu \mathrm{g}$ \\
\hline & & $0.040(0.00 \%)$ & $0.031(22.5 \%)$ & $0.025(37.5 \%)$ & $0.020(50 \%)$ & $0.01(75 \%)$ \\
\hline \multirow{2}{*}{ Sr. No. } & \multirow{2}{*}{ Strains } & \multicolumn{5}{|c|}{ Amount of samples } \\
\hline & & \multicolumn{2}{|c|}{$10 \mu \mathrm{g}$} & $20 \mu \mathrm{g}$ & $40 \mu \mathrm{g}$ & $80 \mu \mathrm{g}$ \\
\hline 1 & HD70.5 & \multicolumn{2}{|c|}{$0.035(12.5 \%)$} & $0.034(15 \%)$ & $0.032(20 \%)$ & $0.028(30 \%)$ \\
\hline 2 & HD1.3 & \multicolumn{2}{|c|}{$0.034(15 \%)$} & $0.033(17.5 \%)$ & $0.030(25 \%)$ & $0.027(32.5 \%)$ \\
\hline 3 & HD38.8 & \multicolumn{2}{|c|}{$0.033(17.5 \%)$} & $0.030(25 \%)$ & $0.026(35 \%)$ & $0.023(42.5 \%)$ \\
\hline 4 & HD61.6 & \multicolumn{2}{|c|}{$0.034(15 \%)$} & $0.033(17.5 \%)$ & $0.029(27.5 \%)$ & $0.033(32.5 \%)$ \\
\hline 5 & HD56.7 & \multicolumn{2}{|c|}{$0.035(12.5 \%)$} & $0.031(22.5 \%)$ & $0.027(32.5 \%)$ & $0.025(37.5 \%)$ \\
\hline 6 & HD11.2 & \multicolumn{2}{|c|}{$0.037(7.5 \%)$} & $0.034(15 \%)$ & $0.033(17.5 \%)$ & $0.031(22.5 \%)$ \\
\hline 7 & HD43.1 & \multicolumn{2}{|c|}{$0.036(10 \%)$} & $0.035(12.5 \%)$ & $0.032(20 \%)$ & $0.029(27.5 \%)$ \\
\hline 8 & HD68.8 & \multicolumn{2}{|c|}{$0.034(15 \%)$} & $0.030(25 \%)$ & $0.025(37.5 \%)$ & $0.024(40 \%)$ \\
\hline 9 & HD23.7 & \multicolumn{2}{|c|}{$0.038(5 \%)$} & $0.037(7.5 \%)$ & $0.035(12.5 \%)$ & $0.030(25 \%)$ \\
\hline 10 & N7 & \multicolumn{2}{|c|}{$0.030(25 \%)$} & $0.023(42.5 \%)$ & $0.019(52.5 \%)$ & $0.017(57.5 \%)$ \\
\hline 11 & HD65.4 & \multicolumn{2}{|c|}{$0.035(12.5 \%)$} & $0.033(17.5 \%)$ & $0.030(25 \%)$ & $0.027(32.5 \%)$ \\
\hline 12 & HD49.6 & \multicolumn{2}{|c|}{$0.038(5 \%)$} & $0.037(7.5 \%)$ & $0.035(12.5 \%)$ & $0.032(20 \%)$ \\
\hline 13 & HD2.1 & \multicolumn{2}{|c|}{$0.032(20 \%)$} & $0.030(25 \%)$ & $0.028(30 \%)$ & $0.026(35 \%)$ \\
\hline 14 & HD8.8 & \multicolumn{2}{|c|}{$0.038(5 \%)$} & $0.036(10 \%)$ & $0.034(15 \%)$ & $0.029(27.5 \%)$ \\
\hline 15 & HD63.7 & \multicolumn{2}{|c|}{$0.034(15 \%)$} & $0.032(20 \%)$ & $0.029(27.5 \%)$ & $0.028(30 \%)$ \\
\hline
\end{tabular}

Note: The values in parenthesis indicated inhibition percentages of NBT reduction.

From Station 2, S. fimicola strain S2 showed 55\% inhibition of NBT reduction at $80 \mu \mathrm{g}$ of filtrate protein and was found to be the most efficient strain in SOD enzyme activity (Table 3). However, strains IQ36.5 and IQ8.4 showed $42.5 \%$ and $40 \%$ inhibition of NBT reduction, respectively, and were found to be the second and third most efficient strains (Table 3). Least inhibition percentage of NBT reduction was observed for strain IQ27.7, and even $80 \mu \mathrm{g}$ protein of filtrate caused only $17.5 \%$ inhibition of NBT reduction (Table 3). The remaining strains of $S$. fimicola from Station 2 exhibited the same level of inhibition of NBT in the range of $22.5-37.5 \%$ (Table 3 ).

From station 6, strain N6 was found to be the most efficient in SOD enzyme activity and showed 55\% inhibition of NBT reduction at $20 \mu \mathrm{g}$ of filtrate protein as compared to other strains, which showed less than $50 \%$ inhibition of NBT reduction at $80 \mu \mathrm{g}$ of filtrate protein (Table 4). Strains MQ13.4 and MQ5.4 showed 42.5\% and $40 \%$ inhibition of NBT reduction, respectively, and were found to be the second most-efficient strains for SOD production (Table 4). Strain MQ11.2 showed the least inhibition of NBT reduction at maximum amount of protein, i.e., $80 \mu \mathrm{g}$ of this strain caused only $20 \%$ inhibition of NBT reduction (Table 4). The remaining strains of $S$. fimicola from Station 6 showed lower levels of inhibition of NBT in the range of $22.5 \%-37.5 \%$ (Table 4 ).

In station 7, S. fimicola strain N7 was found to be most active in SOD production and showed $52.5 \%$ inhibition of NBT reduction at $40 \mu \mathrm{g}$ of filtrate protein compared to other strains from this station (Table 5). Strains HD38.8 and HD68.8 showed $42.5 \%$ and $40 \%$ inhibition of NBT reduction, respectively (Table 5). However, strain HD49.6 showed the least inhibition percentage of NBT (20\%) at $80 \mu \mathrm{g}$ of filtrate protein (Table 5). The remaining strains of Station 7 showed a level of inhibition of NBT in the range of $22.5-37.5 \%$ and were comparatively less efficient for SOD production than N7 isolate from Station 7 (Table 5).

\section{DNA Extraction and Ribotyping}

Five S. fimicola strains with maximum SOD enzyme activities, i.e., S1, S2, N6, N7, and SF13 from different environments were undergone for SOD-1 gene amplification and sequencing. Genomic DNA was isolated and a DNA band of $\sim 15 \mathrm{~Kb}$ was observed on gel electrophoresis. Ribotyping results revealed that sequences of the hypervariable (V4) domain of 18S rRNA gene were 


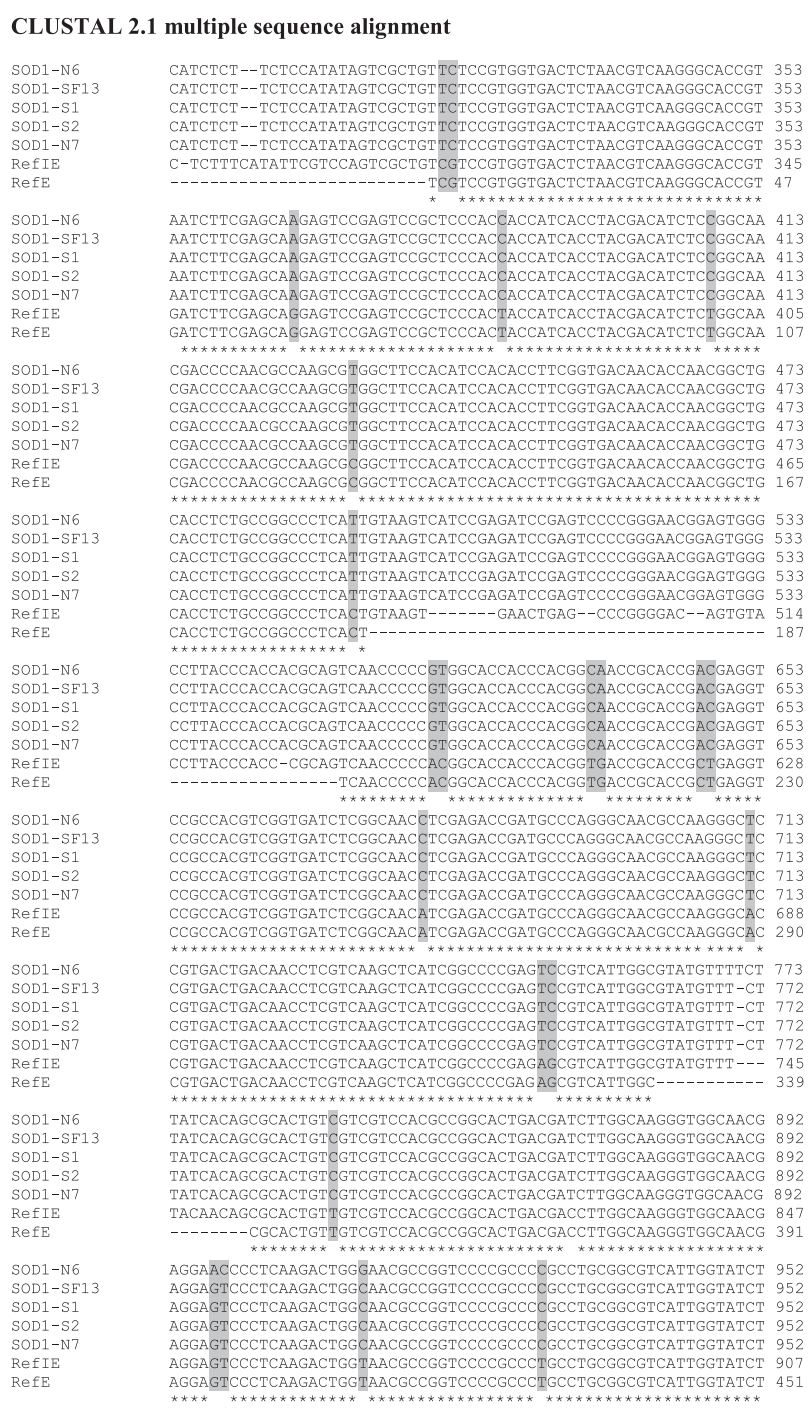

Fig. 1. Multiple sequence alignments of the truncated SOD-1 genes isolated from the different strains of S. fimicola (S1, S2, N6, N7, and SF13).

Key: RefIE: SOD-1 complete gene (Accession \# M58687.1) of $N$. crassa with exons and introns (915 bp); RefE: SOD-1 complete gene (Accession \# M58687.1) of $N$. crassa with exons only.

$100 \%$ similar to each other as well as with the previously reported sequence of S. fimicola (AY545724.1).

\section{SOD-1 Gene Analysis}

The complete SOD-1 gene including exons and introns was amplified and compared with the reference sequence of N. crassa (M58687.1) using ClustalW software. A total of 25 types of base substitutions were observed in all five strains of $S$. fimicola. Twenty base substitutions were common in all five strains of S. fimicola with $100 \%$ prevalence, while G(396)A, T(397)C, and T(411)G were present only in strain N6 (with $20 \%$ prevalence), and $\mathrm{T}(411) \mathrm{C}$ was present in four strains of $S$. fimicola (except strain N6 with $80 \%$ prevalence; Fig. 1), which resulted in seven amino acid changes at different positions of all five strains of $S$. fimicola (Fig. 2). Amino acid changes $\mathrm{V}(6) \mathrm{L}, \mathrm{H}(66) \mathrm{R}, \mathrm{D}(72) \mathrm{N}, \mathrm{A}(75) \mathrm{D}, \mathrm{I}(83) \mathrm{L}$, and $\mathrm{T}(94) \mathrm{S}$ were common in all five strains of S. fimicola with $100 \%$ prevalence; however, S(133)P amino acid change was present only in strain N6 with $20 \%$ prevalence (Table 6, Fig. 2).

The deduced SOD protein from all five strains of $S$. fimicola and from the reference protein of $N$. crassa (M58687.1) was 152 amino acids long, but this protein has different molecular weight $(15,714.2 \mathrm{Da})$ compared to other SOD proteins with molecular weights $(15,776.3$ Da) derived from four strains of $S$. fimicola (Table 7). However, in the case of N6 strain, a molecular weight of 15,786.3 Da was calculated (Tables 7). As reference SOD protein from $N$. crassa was altered at seven amino acid positions, the isoelectric point of this protein was found to be 5.74 instead of 5.82 for SOD proteins from all five strains of $S$. fimicola (Table 7). The PTMs of the SOD proteins were predicted to be common among all five strains of S. fimicola (Table 8).

\section{Phylogenetic Analysis}

Phylogenetic analysis based on the SOD-1 protein sequence was performed for five $S$. fimicola strains belonging to different habitats (Fig. 3). This analysis showed that Sordaria species clustered in a separate clade I, while the sequences of Aspergillus species lie in clade II. Furthermore, clade I split into three (3) sub-clades: sub-clades I and II have the sequence of Sordaria spp., while Sordaria macrospora separated into sub-clade III.

\section{Discussion}

The SOD activities have been reported from different organisms, including fungi, insects, plants, and mammals, and its molecular characterization has been carried out in numerous fungal species [18]. In the current research, among the 10 isolates of $A$. niger, strain 744 showed the maximum SOD enzyme activity and caused $60 \%$ inhibition of NBT reduction at $40 \mu \mathrm{g}$ of filtrate protein (Table 1). However, strain 840 was found to have the least SOD enzyme activity and caused only $22.5 \%$ inhibition of NBT reduction - even at $80 \mu \mathrm{g}$ protein of the fungal filtrate (Table 1).

Among 61 isolates of $S$. fimicola the N6 strain was found to be most efficient regarding SOD production and only $20 \mu \mathrm{g}$ of filtrate protein caused $50 \%$ inhibition of NBT (Table 4). While S. fimicola strains S1 and N7 were found to be the second most efficient strains for SOD enzyme activity and 50\% inhibition of NBT reduction was achieved at a concentration of $40 \mu \mathrm{g}$ (Tables 2, 5). However, the S. fimicola strain SF13 belonging to humid continental environment showed $45 \%$ inhibition of NBT reduction at a concentration of $80 \mu \mathrm{g}$ and was found to be in top five isolates for SOD production (Table 2). The biochemical properties of superoxide dismutase isolated 


\section{CLUSTAL 2.1 multiple sequence alignment}

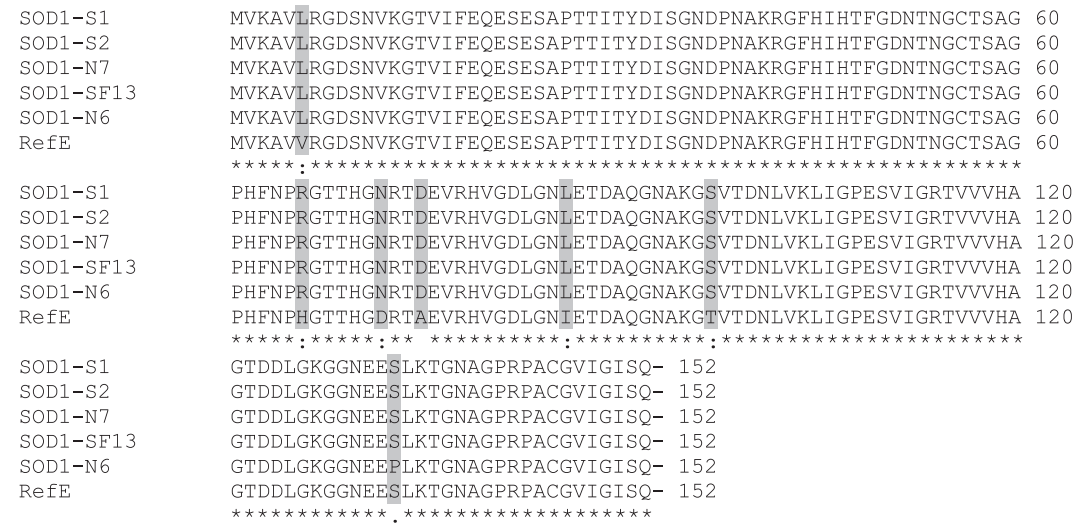

Fig. 2. Multiple sequence alignments of superoxide dismutase proteins isolated from different strains of S. fimicola along reference proteins derived from the nucleotide sequence of the N. crassa Superoxide dismutase complete gene (Accession no. M58687.1) with exons only.

Key: RefE: Superoxide dismutase complete protein derived from complete gene (Accession No. M58687.1) of $N$. crassa; SOD from Strain S1: SOD1-S1; SOD from Strain S2: SOD1-S2; SOD from Strain N6: SOD1-N6; SOD from Strain N7: SOD1-N7 and SOD from Strain SF13: SOD1-SF13.

from N. crassa and Fusaium oxysporum were also reported in earlier literature [19]. Molecular and biochemical approaches have been used to identify Abdopus aculeatus and Acuba japonicas [20].

Five S. fimicola strains (S1, S2, N6, N7, and SF13) with maximum SOD enzyme activity were subjected to ribotyping and molecular analysis for SOD-1 gene. The ribotyping results revealed that 431 bases long V4 domain region of $18 \mathrm{~S}$ rRNA gene was $100 \%$ identical with the previously reported sequence of S. fimicola (AY545724.1), which confirmed that $S$. fimicola strains were pure cultures without any contamination. The sequences of V4 domain of S. fimicola strains S1, S2, N6, N7, and SF13 were submitted to the NCBI database under accession numbers KF487278, KF487279, KF487281, KF487282, and LM654514, respectively. The 18S rRNA gene sequencing was used earlier for species identification in different studies [21].

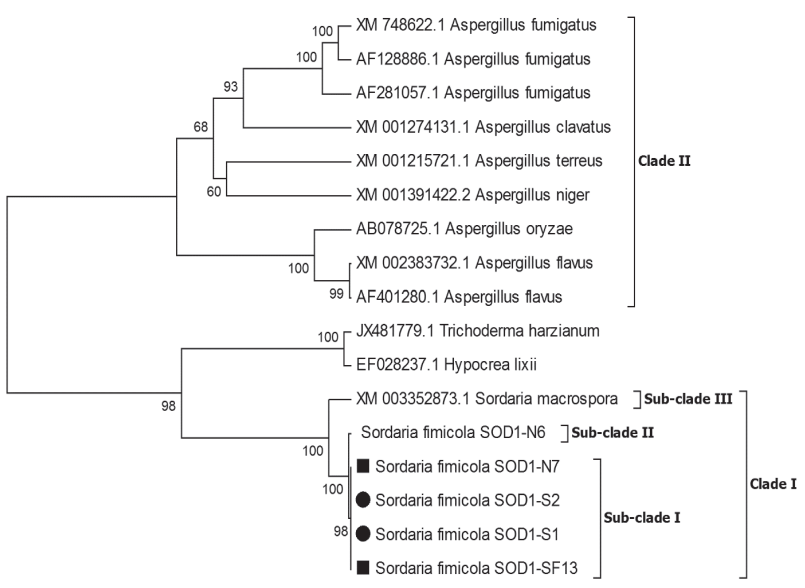

Fig. 3. Phylogenetic relationship of S. fimicola based on the superoxide dismutase gene using the maximum likelihood method.

Table 6. Amino acid substitutions in superoxide dismutase proteins derived from different strains of S. fimicola.

\begin{tabular}{|c|c|c|c|c|c|c|c|}
\hline $\begin{array}{c}\text { Sr. } \\
\text { no. }\end{array}$ & $\begin{array}{c}\text { Amino acid substitutions in } \\
\text { exons of the gene }\end{array}$ & SOD1-S1 & SOD1-S2 & SOD1-N6 & SOD1-N7 & SOD1-SF13 & $\begin{array}{c}\text { Percentage Prevalence } \\
(\%)\end{array}$ \\
\hline 1 & $\mathrm{~V}(6) \mathrm{L}$ & + & + & + & + & + & 100 \\
\hline 2 & $\mathrm{H}(66) \mathrm{R}$ & + & + & + & + & + & 100 \\
\hline 3 & $\mathrm{D}(72) \mathrm{N}$ & + & + & + & + & + & 100 \\
\hline 4 & $\mathrm{~A}(75) \mathrm{D}$ & + & + & + & + & + & 100 \\
\hline 5 & $\mathrm{I}(83) \mathrm{L}$ & + & + & + & + & + & 100 \\
\hline 6 & $\mathrm{~T}(94) \mathrm{S}$ & + & + & + & + & 100 \\
\hline 7 & $\mathrm{~S}(133) \mathrm{P}$ & & + & & & 20 \\
\hline
\end{tabular}

Note: Amino acid substitutions were detected in comparison with superoxide dismutase complete gene and protein (Accession No. M58687.1) of N. crassa.

Key: SOD from Strain S1: SOD1-S1; SOD from Strain S2: SOD1-S2; SOD from Strain N6: SOD1-N6; SOD from Strain N7: SOD1-N7 and SOD from Strain SF13: SOD1-SF13. 
Table 7. Analysis of superoxide dismutase proteins derived from different strains of S. fimicola using the ExPASy ProtParam tool.

\begin{tabular}{|c|c|c|c|c|c|}
\hline Strains & No. of Amino acid & $\begin{array}{c}\text { Mol. Wt. of Protein } \\
\text { (Daltons) }\end{array}$ & PI. of Protein & $\begin{array}{c}\text { Gene length (Exons) } \\
\text { (bp) }\end{array}$ & Dominated Amino acid (\%) \\
\hline RefE & 152 & $15,714.2$ & 5.74 & 456 & Gly (G) 15.1 \\
\hline SOD1-S1 & 152 & $15,776.3$ & 5.82 & 456 & Gly (G) 15.1 \\
\hline SOD1-S2 & 152 & $15,776.3$ & 5.82 & 456 & Gly (G) 15.1 \\
\hline SOD1-N6 & 152 & $15,786.3$ & 5.82 & 456 & Gly (G) 15.1 \\
\hline SOD1-N7 & 152 & $15,776.3$ & 5.82 & 456 & Gly (G) 15.1 \\
\hline SOD1-SF13 & 152 & $15,776.3$ & 5.82 & 456 & Gly (G) 15.1 \\
\hline
\end{tabular}

Key: SOD from Strain S1: SOD1-S1; SOD from Strain S2: SOD1-S2; SOD from Strain N6: SOD1-N6;

SOD from Strain N7: SOD1-N7 and SOD from Strain SF13: SOD1-SF13; RefE: Superoxide dismutase complete reference gene protein (Accession no. M58687.1) of N. crassa; PI: Isoelectric point of protein.

Table 8. Predictions of protein translation modifications in SOD proteins using different servers.

\begin{tabular}{|c|c|c|c|c|c|}
\hline \multirow{2}{*}{$\begin{array}{l}\text { Servers used } \\
\text { to predict PTMs }\end{array}$} & \multirow{3}{*}{ Serial number } & \multicolumn{4}{|c|}{ SOD } \\
\hline & & S1 & $\mathrm{S} 2$ & N6 & $\mathrm{N} 7$ \\
\hline \multirow{7}{*}{ LysAcet } & & \multicolumn{4}{|c|}{ Acetylation } \\
\hline & 1 & K13 & K13 & K13 & K13 \\
\hline & 2 & K41 & K41 & K41 & K41 \\
\hline & 3 & K95 & K95 & K95 & K95 \\
\hline & 4 & K104 & K104 & K104 & K104 \\
\hline & 5 & K127 & K127 & K127 & K127 \\
\hline & 6 & K135 & K135 & K135 & K135 \\
\hline \multirow{6}{*}{ PredMod } & Sr. no. & S1 & S2 & N6 & N7 \\
\hline & 1 & $\mathrm{~K} 3$ & K3 & K3 & K3 \\
\hline & 2 & K41 & K41 & K41 & K41 \\
\hline & 3 & K104 & K104 & K104 & K104 \\
\hline & 4 & K127 & K127 & K127 & K127 \\
\hline & 5 & K135 & K135 & K135 & K135 \\
\hline \multirow{3}{*}{$B P S$} & \multicolumn{5}{|c|}{ Methylation } \\
\hline & Sr. no. & S1 & S2 & N6 & N7 \\
\hline & 1 & K104 & K104 & K104 & K104 \\
\hline \multirow{4}{*}{ DISPHOS } & \multicolumn{5}{|c|}{ Phosphorylation } \\
\hline & Sr. no. & S1 & S2 & N6 & N7 \\
\hline & 1 & Y31 & Y31 & Y31 & Y31 \\
\hline & 2 & T57 & T57 & T57 & T57 \\
\hline \multirow{2}{*}{ YinOYang } & Sr. no. & S1 & $\mathrm{S} 2$ & N6 & N7 \\
\hline & & Nil & Nil & Nil & Nil \\
\hline \multicolumn{6}{|c|}{ Glycosylation } \\
\hline \multirow{2}{*}{ NetNGlyc 1.0} & Sr. no. & S1 & S2 & N6 & N7 \\
\hline & 1 & N72 & N72 & N72 & N72 \\
\hline
\end{tabular}


Table 8. Continued.

\begin{tabular}{|c|c|c|c|c|cc|}
\hline \multirow{4}{*}{ YinOYang } & Sr. no. & S1 & S2 & N6 & N7 \\
\cline { 2 - 7 } & 1 & T28 & T28 & T28 & T28 \\
\cline { 2 - 7 } & 2 & T30 & T30 & T30 & T30 \\
\cline { 2 - 7 } & 3 & T57 & T57 & S151 & S151 \\
\cline { 2 - 7 } & 4 & S151 & S151 & T57 & \\
\cline { 2 - 7 }
\end{tabular}

Note: Amino acid abbreviations, K-Lysine (Lys); N-Asparagine (Asn); S-Serine (Ser); T-Threonine (Thr); Y-Tyrosine (Tyr).

For the amplification of the SOD-1 gene, a sequence of $N$. crassa (M58687.1) was used to design the primers because the genomic sequence of $N$. crassa was found most closely related to $S$. macrospora than any other sequenced filamentous fungi [22-23]. When SOD-1 gene sequences were aligned with the reference gene of the $N$. crassa (M58687.1), a total of 25 base substitutions were observed in the exonic region (Fig. 1), as a result of which seven amino acids changes were found in all five strains of S. fimicola (Fig. 2), and that may have an impact on the activity of SOD enzyme of N6 strain of S. fimicola as evident in biochemical assays. The deduced SOD proteins in all five strains of $S$. fimicola as well as of the $N$. crassa (M58687.1) were 152 amino acids long. But the molecular weight $(15,714.2 \mathrm{Da})$ and isoelectric point (5.74) of the $N$. crassa (M58687.1) were different from the molecular weights $(15,776.3 \mathrm{Da})$ and isoelectric point (5.82) derived from the four strains of $S$. fimicola due to the prevalence of amino acid changes at seven positions, which resulted in a shift of molecular weight of the SOD protein (Table 6). However, in the case of the N6 strain of S. fimicola, 15,786.3 Da molecular weight was observed, which was attributed due to S(133)P change prevailing only in this strain and absent in all other strains (Table 6). The molecular weights of SOD proteins from different strains of $S$. fimicola in the current research were close to findings described earlier [8], which reported that the 153 amino acid sequence of copper-zinc superoxide dismutase in $N$. crassa has a molecular weight of 15,850 Da. The $\mathrm{Cu} / \mathrm{Zn}$ (SOD) gene from Cordeceps militaris with a deduced 154 amino acids that shows $72-95 \%$ sequence similarities to $\mathrm{Cu} / \mathrm{Zn}$ (SOD) from other fungi has been described earlier [24]. Four SOD genes in the genome of the A. fumigates have been reported and proteins of these genes provide protection to the organisms against oxidative stress [25]. PTMs are means of important mechanisms for the proper functioning of proteins [26]. The interplay between different PTMs such as phosphorylation and glycosylation, phosphorylation and acetylation, and phosphorylation and methylation is known to play a key role in the functional regulation of different proteins [27]. The PTMs were common among the five strains of $S$. fimicola (Table 8). It is reported that Ceriporiopsis subvermispora has a single laccase gene and its multiple isoforms are formed by the process of PTMs, possibly by glycosylation and phosphorylation [28].
Phylogenetic analysis was carried out based on SOD-1 genes from five $S$. fimicola strains belonging to different habitats (Fig. 3). Phylogenetic analysis showed that $S$. macrospora has a close evolutionary relationship with $S$. fimicola, as both species separated under a significance bootstrap value of 100 . This genetic diversity and genetic modification of the N6 strain was also quite evident in transcriptional and translational product, as the molecular weight of N6 strain was 10 Daltons more than other strains of $S$. fimicola $(15,786.3-15,776.3=10$; Table 7). The SOD genes from different organisms can be utilized in phylogenetic analysis [29]. The phylogenetic approach by using 20 partial SOD sequences from 19 clinical fungal isolates to study the diversity in Ascomycota and Basidiomycota fungi has been reported [30].

\section{Conclusions}

In the current study, SOD-1 gene sequences were reported in S. fimicola and submitted to the NCBI database under accession numbers KM282177, KM282178, KM282179, KM282181, and KM282180 for strains SF13, S1, S2, N7, and N6, respectively. The biochemical as well as molecular results of the study showed that environmental stresses affected S. fimicola SOD enzyme activity and isoelectric points of the SOD protein, as well as the gene by producing changes in its nucleotide sequence. The SOD enzyme activity of S. fimicola strains was found comparable to A. niger. Therefore, being a saprophytic with short life cycle, S. fimicola can become a fungus of choice for SOD enzyme production on a large scale.

\section{Acknowledgements}

Our work was financially supported by the Higher Education Commission (HCE), Islam Abad, under the International Research Support Initiative Program and by a special research grant given by the vice chancellor, University of the Punjab (New Campus), Lahore. We thankfully acknowledge the help of Dr. Youfu "Frank" Zhao in the Crop Sciences Department at the University of Illinois at Urbana-Champaign, USA. 


\section{References}

1. GHORAI S., BANIK S.P., VERMA D., CHOWDURY S., MUKHERJEE S., KHOWALA S. Fungal biotechnology in food and feed processing. Food Res. Int. 42, 577, 2007.

2. KAVAK H. Some Biological Parameters in Sordaria fimicola. Pak. J. Bot. 44, 1079, 2012

3. ARCHER D.B., CONNERTON I.F., MACKENZIE D.A. Filamentous fungi for production of food additives and processing aids. Adv. Biochem. Eng. Biot. 111, 99, 2008.

4. YOUSEFF B.H., HOLBROOK E.D., SMOLNYCKI K. A., RAPPLEYE C.A. Extracellular Superoxide Dismutase Protects Histoplasma Yeast Cells from Host-Derived Oxidative Stress. PLoS Pathog. 8, 2012.

5. FROHNER I.E., BOURGEOIS C., YATSYK K., MAJER O., KUCHLER K. Candida albicans cell surface superoxide dismutases degrade host-derived reactive oxygen species to escape innate immune surveillance. Mol. Microbiol. 71, 240, 2009.

6. ZHANG N., ZHANG S., BORCHERT S., RICHARDSON K., SCHMID J. High Levels of a Fungal Superoxide Dismutase and Increased Concentration of a PR-10 Plant Protein in Associations Between the Endophytic Fungus Neotyphodium lolii and Ryegrass. 24, 984, 2011.

7. ZHENG L.P., GAO L.W., ZHOU J.Q., SIMA Y.H., WANG J.W. Antioxidant activity of aqueous extract of a Tolypocladium sp. fungus isolated from wild Cordyceps sinensis. Afric. J. Biotech. 7, 3004, 2008.

8. ZHANG L.Q., GUO F.X., XIAN H.Q., WANG X.J. Expression of a novel thermostable $\mathrm{Cu} / \mathrm{Zn}$-superoxide dismutase from Chaetomium thermophilum in Pichia pastoris and its antioxidant properties. Biotechnol. Lett. 33, 1127, 2011.

9. LI H., SUN X., CAI Z., CAI G., XING K. Identification and analysis of a $\mathrm{Cu} / \mathrm{Zn}$ superoxide dismutase from Haliotis diversicolor supertexa with abalone juvenile detached syndrome. J. Invertebr. Pathol. 103, 116, 2010.

10. DONG C., LI G., LI Z., ZHU H., ZHOU M., HU Z. Molecular cloning and expression analysis of a Mn-SOD gene from Nelumbo nucifera. Appl. Biochem. Biotechnol. 158, 605, 2009.

11. XU X., ZHOU Y., WEI S., REN D., YANG M., BU H., KANG M., WANG J., FENG J. Molecular cloning and expression of a $\mathrm{Cu} / \mathrm{Zn}$-containing superoxide dismutase from Thellungiella halophile. Mol. Cells. 27, 423, 2009.

12. NEVO E. "Evolution Canyon," a potential microscale monitor of global warming across life. Pro. Natl. Acad. Sci. 109: 2960, 2012

13. ISHFAQ M., MAHMOOD N., NASIR I.A., SALEEM M. Molecular and Biochemical screening of local Aspergillus niger strains efficient in catalase and laccase enzyme production. Int. J. Agri. Biol. 16, 177, 2014.

14. BRADFORD M.M. Rapid and sensitive method for the quantitation of microgram quantities of protein utilizing the principle of protein-dye binding. Anal. Biochem. 72, 248, 1976

15. NASIM G., KHAN S., KHOKHAR I. Molecular polymorphism and phylogenetic relationship of some Alternaria alternate isolates. Pak. J. Bot. 44, 642, 2012.

16. HANIF M., KHALID A.N., SAMINA S. Addition to the ectomycorrhizae associated with Hamalaya cydar $(C$. deodara) using rDNA-ITS. Int. J. Agr. Biol. 14, 101, 2012.
17. TAMURA K., STECHER G., PETERSON D., FILIPSKI A., KUMAR S. MEGA6: Molecular Evolutionary Genetics Analysis version 6.0. Mol. Bio. Evo. 30, 2725, 2013.

18. HOFFMEISTER D., KELLER N.P. Natural products of filamentous fungi: enzymes, genes, and their regulation. Nat. Prod. Rep. 24, 393, 2007.

19. LERCH K., SCHENK E. Primary structure of copper-zinc superoxide dismutase from Neurospora crassa. J. Biol. Chem. 260, 9559, 1985.

20. PARENICOVA L., SKUBOE P., FRISVAD J., SAMSON R.A., ROSSEN L., TEN HOOR-SUYKERBUYK M., VISSER J. Combined molecular and biochemical approach identifies Aspergillus japonicus and Aspergillus aculeatus as two species. Appl. Environ. Microbiol. 67, 521, 2001.

21. MEYER A., TODT C., MIKKELSEN N.T., LIEB B. Fast evolving 18S rRNA sequences from Solenogastres (Mollusca) resist standard PCR amplification and give new insights into mollusk substitution rate heterogeneity. BMC. EVOL. Biol. 10, 56, 2010.

22. NOWROUSIAN M., STAJICH J.E., CHU M., ENGH I., ESPAGNE E., HALLIDAY K., KAMEREWERD J., KEMPKEN F., KNAB B., KUO H.C., OSIEWACZ H.D., POGGELER S., READ N.D., SEILER S., SMITH K.M., ZICKLER D., KUCK U., FREITAG M. De novo assembly of a $40 \mathrm{Mb}$ eukaryotic genome from short sequence reads: Sordaria macrospora, a model organism for fungal morphogenesis. PLoS Genet. 6, 2010.

23. TEICHERT I., WOLFF G., KUCK U., NOWROUSIAN M. Combining laser microdissection and RNA-seq to chart the transcriptional landscape of fungal development. BMC. Genomics. 13, 511, 2012.

24. ZHOU X.W., WANG X.F., LI Q.Z. Expression and characteristic of the $\mathrm{Cu} / \mathrm{Zn}$ superoxide dismutase gene from the insect parasitizing fungus Cordyceps militaris. Mol. Biol. Rep. 39, 10303, 2012.

25. LAMBOU K., LAMARRE C., BEAU R., DUFOUR N., LATGE J. Functional analysis of the superoxide dismutase family in Aspergillus fumigatus. Mol. Biol. 74, 910, 2010.

26. KALEEM A., AHMAD I., SHAKOORI A.R., NASIR-UDDIN. Regulation of neurofibromin by post-translational modification. Pak. J. Zool. 40, 417, 2008.

27. TOMONAGAT., MATSUSHITAK., YAMAGUCHI S., OHISHI M., KODERA Y., MAEDA T., HIDEAKI SHIMADA, OCHIAI T., NOMURA F. Identification of altered protein expression and post-translational modifications in primary colorectal cancer by using agarose two-dimensional gel electrophoresis. Clin. Cancer Res. 10, 2007, 2004.

28. LARRONDO L.F., AVILA M., SALA L., CULLEN D., VICUN T. Heterologous expression of laccase cDNA form Ceriporiopsis subvermispora yields copper-activated apoprotein and complex isoform patterns. Microbiology. 149, 1177, 2003.

29. TANABE Y., SAIKAWA M., WATANABE M.M. SUGIYAMA J. Molecular phylogeny of Zygomycota based on EF-1alpha and RPB1 sequences: limitations and utility of alternative markers to rDNA. Mol. Phylogenet. Evol. 30, 438, 2014.

30. FRÉALLE E., NOËL C., NOLARD N., SYMOENS F., FELIPE M., DEI-CAS E., CAMUS D., VISCOGLIOSI E., DELHAES L. Manganese superoxide dismutase based phylogeny of pathogenic fungi. Mol. Phylogenet. Evol. 41, $28,2006$. 
